\title{
Prevalence of Mental Disorders and Recidivism in Young Offenders
}

\section{Prevalência de Transtornos Mentais e Reincidência em Menores Infratores}

\author{
Álvaro Machado Dias*, ${ }^{*}$, Antonio de Pádua Serafim ${ }^{b, c}$ \& Daniel Martins de Barros ${ }^{b}$ \\ ${ }^{a}$ Universidade Federal de São Paulo, São Paulo, São Paulo, Brasil, \\ ${ }^{b}$ Núcleo de Apoio à Pesquisa em Neurociência Aplicada/USP, São Paulo, São Paulo, Brasil \\ 'Universidade Metodista de São Paulo, São Paulo, Brasil
}

\begin{abstract}
Several studies report that incarcerated young offenders show a high rate of psychiatric disorders whereas associations between specific psychiatric disorders and recidivism remain unknown. The Brazilian legal system has created a unique opportunity for the study of this issue when consider young offenders not that guilty in spite of the severity of the crime, settling in three years the maximum period of incarceration. This study aims to determine the rate of psychiatric disorders in a cohort of incarcerated young offenders and evaluate the possible psychiatric connections of primary offenders and recidivism. A group of 898 incarcerated young offenders at Fundação Casa answered psychiatric interviews and was diagnosed according to the criteria of ICD-10. Statistic connections were analyzed using the tests of Pearson and Cramer. The cohort was comprised of 619 primaries and 267 recidivists. 'Psychoactive Substance Use' and 'Disorders of Adult Personality and Behavior' categories were related to recidivism, whereas 'Organic Mental Disorders', 'Mood Disorders', and 'Stress-related Disorders' were related to primary offenders. Discriminating disorders were the most likely to represent reactions to primary incarceration. In relation to associations that might represent predictors of crime, it became highly suggestive that substance abuse is the main cause of incarceration for the entire cohort.
\end{abstract}

Keywords: Young offenders, psychiatric disorders, recidivism, psychiatric epidemiology.

\begin{abstract}
Resumo
Diversos estudos revelam que jovens infratores encarcerados apresentam taxas aumentadas de transtornos psiquiátricos, ao passo que associações entre transtornos específicos e reincidência permaneçam desconhecidas. O sistema legal brasileiro criou uma oportunidade exclusiva para o estudo desta questão, conforme considera os menores não imputáveis, a despeito da severidade do crime, fixando em três anos o período máximo de encarceramento. Este estudo pretende determinar a taxa de transtornos psiquiátricos em uma coorte de jovens infratores encarcerados e avaliar possíveis conexões entre transtornos específicos encarceramento primário e reincidência criminosa. Um grupo de 898 internos da Fundação Casa foi submetido a entrevistas psiquiátricas e diagnosticado de acordo com os critérios do CID-10. Conexões estatísticas foram analisadas usando os testes de Pearson e Cramer. A coorte tinha 619 primários e 267 reincidentes. Uso de Substância Psicoativa e Desordens da Personalidade e Comportamento Adulto relacionaram-se com reincidência, ao passo que Doenças Mentais Orgânicas, Transtorno do Humor e Desordens Relacionadas ao Estresse apresentaram relação com encarceramento primário. No que tange aos preditores da criminalidade, reforça-se a noção de que o abuso de drogas é a principal causa de encarceramento na amostra investigada.

Palavras-chave: Jovens infratores, transtornos psiquiátricos, reincidência, epidemiologia psiquiátrica.
\end{abstract}

A plethora of studies dealing with juvenile delinquency try to define whether different genetic, epigenetic, and behavioral trends are tied to delinquent behaviors (Cruzeiro et al., 2008; Gallo \& Williams, 2005; Mendes, Mari, Singer, Barros, \& Mello, 2009). Among these studies, it

\footnotetext{
${ }^{*}$ Mailing Address: Laboratório Interdisicplinar de Neurociências Clínicas, Universidade de São Paulo, Rua Pedro de Toledo, 669, Vila Clementino, São Paulo, SP, Brasil 05403-010.E-mail: alvaromd@usp.br, a.serafim@hc.fm. usp.bre dan_barros@yahoo.com.br
}

is possible to notice the existence of a consensus around the assumption that mental disorders either open the door or aggravate delinquent tendencies, in Europe (Kohler, Heinzen, Hinrichs, \& Huchzermeier, 2009; Vreugdenhil, Doreleijers, Vermeiren, Wouters, \& Van Den Brink, 2004), North America (Eppright, Kashani, Robison, \& Reid, 1993; Ulzen \& Hamilton, 1998) and South America (Pinho, Dunningham, Aguiar, Andrade, \& Guimarães, 2006).

Groups of authors such as Kohler and collaborators (2009) and Teplin, Abram, McClelland, Dulcan and 
Mericle (2002) suggest that psychiatric disorders affect $60-75 \%$ of the convicted youngsters. Among these individuals, personality and substance-related disorders have been argued to be amid the most prominent predictors of incarceration (Ferigolo, Barbosa, Malysz, Stein, \& Barros, 2004; Kohler et al., 2009). However, a question that is still under debate is whether there are stable associations between specific psychiatric disorders and recidivism.

This question becomes particularly prominent as we consider the existence of potential context-related limitations to the attempts of mapping biosocial predictors of progressive crime involvement amongst youngsters (Brennan \& Raine, 1997). In particular, the juridical structure of most developed countries do not favor the deep understanding of recidivism - and this is precisely where most of the research on the matter is carried out.

In general, the type of facility in which a young inmate will pay his sentence depends on the severity of the crime that was committed. Serious crimes and recidivism tend to lead to long-term sentences, which are usually faced in prison, while minor crimes tend to lead to incarceration in juvenile facilities. For that reason, it is sensible to consider that stress levels and, hence, the prevalence of affective psychiatric disorders, are not equivalent between the two.

In contrast to that scenario, Brazilian law regards all minors as non-imputable. At the moment, there is a growing sign of urban violence in Brazil and the participation of youth in this statistic requires Brazilian society to study and analyze the possible causes, as well as to identify and instigate interventional practices. It is well to remember that in 2005, data from the federal government (Department of Promotion of the Rights of the Child and Adolescent) registered only 39,578 young people with a history of infractions. Of these, 14,000 met with measures of incarceration. In the state of Sao Paulo until December 2009, there were 5,000 young people incarcerated for criminal behavior.

Confinement in correctional facilities for adults is only accepted for individuals who have reached the age of eighteen (lawful age) at the date of the crime. From the age of criminal responsibility (which is twelve) to eighteen, juvenile offenders face a limited time of a socio-educational sentence in a correctional facility, which puts together convicted murderers, rapists and drug dealers, together with offenders charged of a misdemeanor.

Moreover, the maximum incarceration period allowed by Brazilian law is three years. The magnitude of this punishment means that a youngster can commit a series of murders, be released, and there will still be time to be re-incarcerated for another series of murders. From that early starting point of being 12 years of age, the offender can be released at the age of eighteen with a completely blank criminal record; in Brazil, the 'conviction bias' related fact, that a serious primary conviction banishes the possibility of recidivism, simply does not hold.

Whether or not this method exposes those who were convicted of minor offences to personal vulnerabilities and increases the risk of recidivism is not the matter under discussion here. However, one thing that can be emphasized is that these peculiarities allow a fair comparison between youngsters enduring their first incarceration and recidivists, thus raising the possibility of examining the role of certain disorders in the classification of criminal leanings, within the context of Brazilian culture. What has in fact transpired is that, over the years, little has been done in terms of mental health for young people incarcerated, either in São Paulo or in other Brazilian states.

In this study, we have investigated the presence of psychiatric disorders in youngsters, incarcerated in Units of the Public Correctional "Fundação Casa", in the city of São Paulo, Brazil.

\section{Method}

With the implementation of the program for Youth Mental Health Care by the Forensic Unit of the Institute of Psychiatry and the Clinical Hospital of the University of São Paulo Medical School, several previously trained psychiatrists were sent to collaborate weekly in the Health Centers of the various units of Fundação Casa, in the City of São Paulo. This study reports one of the major achievement of this team.

Psychiatric screening comprised a cohort of 898 inmates, who voluntarily agreed to collaborate. All participants provided 'informed consent'. The study was approved by the Ethics Commission for the Analysis of Research Projects of the Clinical Hospital of the School of Medicine of the University of São Paulo.

Of the sample initial sample of 898 subjects, 12 were discarded by socio-demographic inconsistencies, reducing the final sample to 886 inmates. Given the presence of several types of possible confusing factors, the main independent variable used for group discrimination was recidivism, whereas the dependent variables were represented by ICD-10 psychiatric disorders. In that regard, the study included 619 youngsters facing their primary incarceration and 267 recidivists (individuals with more than one conviction). Mean age for the whole cohort was $267 ; 17.2 \pm .24$ years.

Table 1

Socio-Demographic Data for Both Groups. Test t*

\begin{tabular}{lccc}
\hline Variable/Group & $\begin{array}{c}\text { Primaries } \\
n=619\end{array}$ & $\begin{array}{c}\text { Recidivists } \\
n=267\end{array}$ & $p^{*}$ \\
\hline $\begin{array}{l}\text { Age } \\
\text { (years) }\end{array}$ & $17.2 \pm .24$ & $17.2 \pm .22$ & .16 \\
$\begin{array}{l}\text { Schooling } \\
\text { (years) }\end{array}$ & $7.2(2.08)$ & $8.3(1.65)$ & .10 \\
$\begin{array}{l}\text { Prison Time } \\
\text { (meses) }\end{array}$ & $7.1(2.73)$ & $7.6(2.80)$ & .58 \\
\hline
\end{tabular}


Dias, A. M., Serafim, A. P. \& Barros, D. M. (2014). Prevalence of Mental Disorders and Recidivism in Young Offenders.

The young offenders were sentenced for periods that extended between 3 and 17 months, with a mean conviction period of 7.3 months. There was no statistically significant difference between groups for any of the variables (Table 1).

The diagnostic was established through the Brazilian version of the questionnaire MINI (Mini International Neuropsychiatric Interview). This is a structured questionnaire applied quickly (15-30 minutes; Amorim, 2000; Sheehan et al., 1998) and developed to include the DSM-IV and the ICD-10 and validated into Portuguese (Amorim, 2000). Data from twelve participants had to be discarded (mainly due to incomplete information), leaving us with 886 diagnoses.

The Conviction Status of the youngsters remained blind to psychiatrists until the conclusion of the research. Subsequently, for the characterization of recidivism, the file records of the subjects were analyzed, determining those with at least two convictions (recidivists) and those who were convicted for the first time (primaries).

The analyses were based on diagnoses related to the ICD-10/category F, which stands for the section concerning Mental and Behavioral Disorders.

Table 2

General Results for Primaries and Recidivists
In order to evaluate the percentage of psychiatric disorders, the chi-square test was utilized, and any possible associations between psychiatric diagnoses, primary offenders and recidivism was analyzed by Person's chisquare or Cramer's V (where more appropriate) in relation to the nosographic categories (sub-categories of F). This strategy was aimed to overcome the statistical limitations regarding a straightforward analysis of the nosographic categories all at once. To achieve this, 2X2 tables were produced relating to each diagnosis, with 'primaries/ recidivists' as columns and 'yes/no' as lines.

\section{Results}

\section{General Results}

From all 886 participants, $88.2 \%$ were males and the mean age was 17.23. There were 619 primaries and 267 recidivists; the mean age of the primaries was 17.18 and the mean age of the recidivists was 17.36. For both groups, the mode was 18 years old, followed by 17 years of age.

In the psychiatric assessment, 608 youngsters (.69) were diagnosed with a mental and behavioral disorder according to the ICD-10 manual. These were further divided into 360 primaries (.58 of all primaries) and 248 of recidivists (.93 of all recidivists; Table 2 ).

\begin{tabular}{|c|c|c|c|c|c|}
\hline & \multicolumn{3}{|c|}{ Raw Data } & \multicolumn{2}{|c|}{ Probab } \\
\hline & Prim & Recid & Sum & Prim & Recid \\
\hline F00-F09 Organic, including symptomatic, mental disorders & 33 & 4 & 37 & $5.43 \%$ & $.66 \%$ \\
\hline $\begin{array}{l}\text { F10-F19 Mental and behavioral disorders due to psychoactive } \\
\text { substance use }\end{array}$ & 78 & 87 & 165 & $12.83 \%$ & $14.31 \%$ \\
\hline F20-F29 Schizophrenia, schizotypal and delusional disorders & 20 & 7 & 27 & $3.29 \%$ & $1.15 \%$ \\
\hline F30-F39 Mood [affective] disorders & 63 & 29 & 92 & $10.36 \%$ & $4.77 \%$ \\
\hline F40-F48 Neurotic, stress-related and somatoform disorders & 69 & 12 & 81 & $11.35 \%$ & $1.97 \%$ \\
\hline $\begin{array}{l}\text { F50-F59 Behavioral syndromes associated with physiological } \\
\text { disturbances and physical factors }\end{array}$ & 1 & 0 & 1 & $.16 \%$ & $.00 \%$ \\
\hline F60-F69 Disorders of adult personality and behavior & 39 & 66 & 105 & $6.41 \%$ & $10.86 \%$ \\
\hline F70-F79 Mental retardation & 15 & 11 & 26 & $2.47 \%$ & $1.81 \%$ \\
\hline F80-F89 Disorders of psychological development & 3 & 2 & 5 & $.49 \%$ & $.33 \%$ \\
\hline \multirow{3}{*}{$\begin{array}{l}\text { F90-F98 Behavioral and emotional disorders with onset } \\
\text { usually occurring in childhood and adolescence }\end{array}$} & 39 & 30 & 69 & $6.41 \%$ & $4.93 \%$ \\
\hline & 360 & 248 & & $59.21 \%$ & $40.79 \%$ \\
\hline & \multicolumn{2}{|c|}{608} & & \multicolumn{2}{|c|}{$100.00 \%$} \\
\hline
\end{tabular}


As the table suggests, 'Mental and Behavioral Disorders due to Psychoactive Substance Use' was the most prevalent diagnosis within the entire cohort (.27). This was followed by Neurotic, Stress-Related and Somatoform Disorders' (.13). And Disorders of Adult Personality and Behavior' (.17), considering only young people aged 18 or more.

Already cconsidering only the primaries for one moment, the most prevalent diagnosis was 'Mental and Beha- vioral Disorders due to Psychoactive Substance Use' (.22 of all primaries), followed by 'Neurotic, Stress-Related and Somatoform Disorders' (.19), and 'Mood [affective] Disorders' (.18). For the recidivists, the order was 'Mental and Behavioral Disorders due to Psychoactive Substance Use' (.35 of all recidivists), 'Disorders of Adult Personality and Behavior' (.27), and 'Behavioral and Emotional Disorders' with onset usually occurring in childhood and adolescence (.12; Figures 1 and 2).

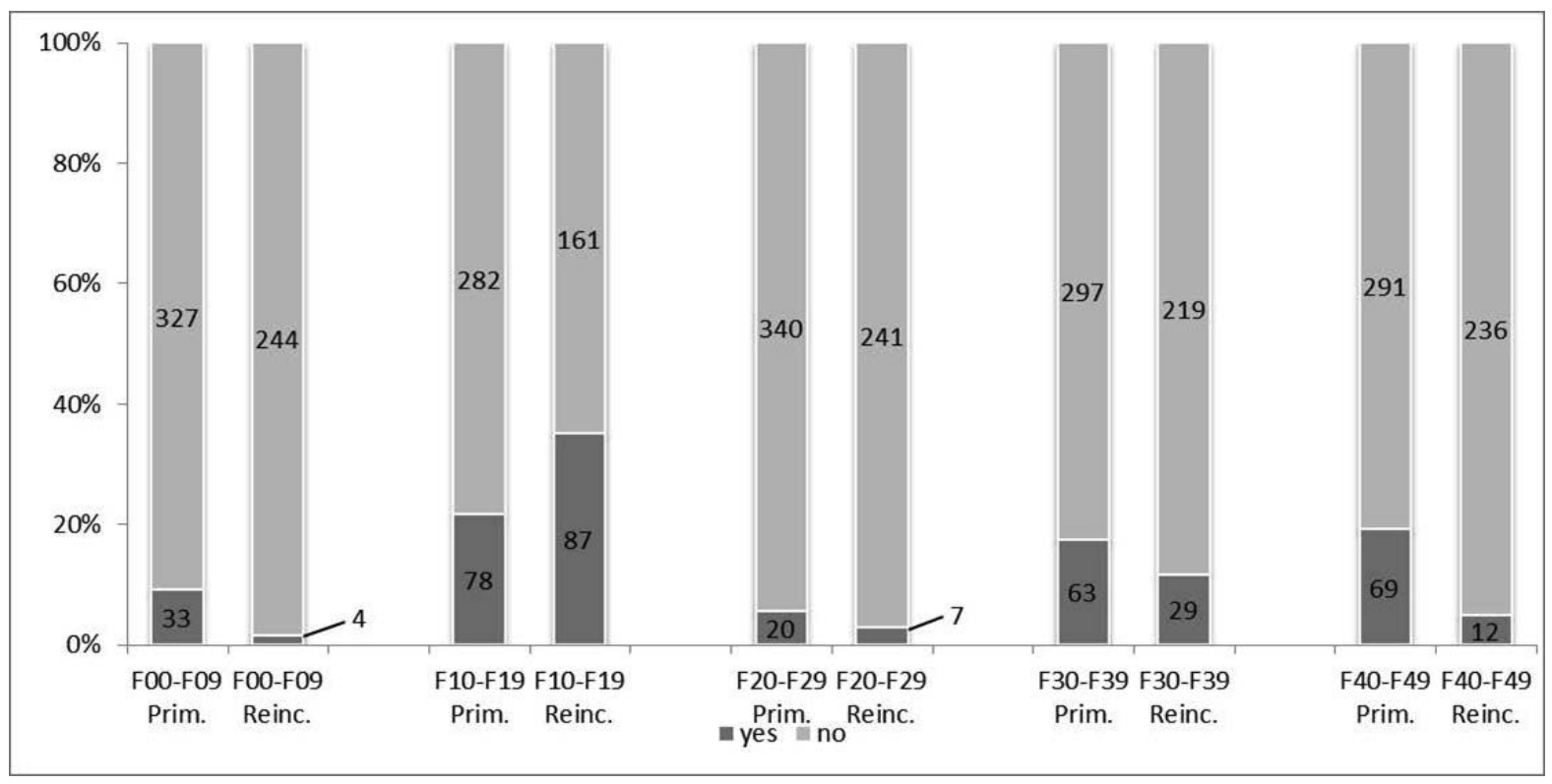

Figure 1. Psychiatric associations to primary and recidivism for F00-F48 (ICD-10).

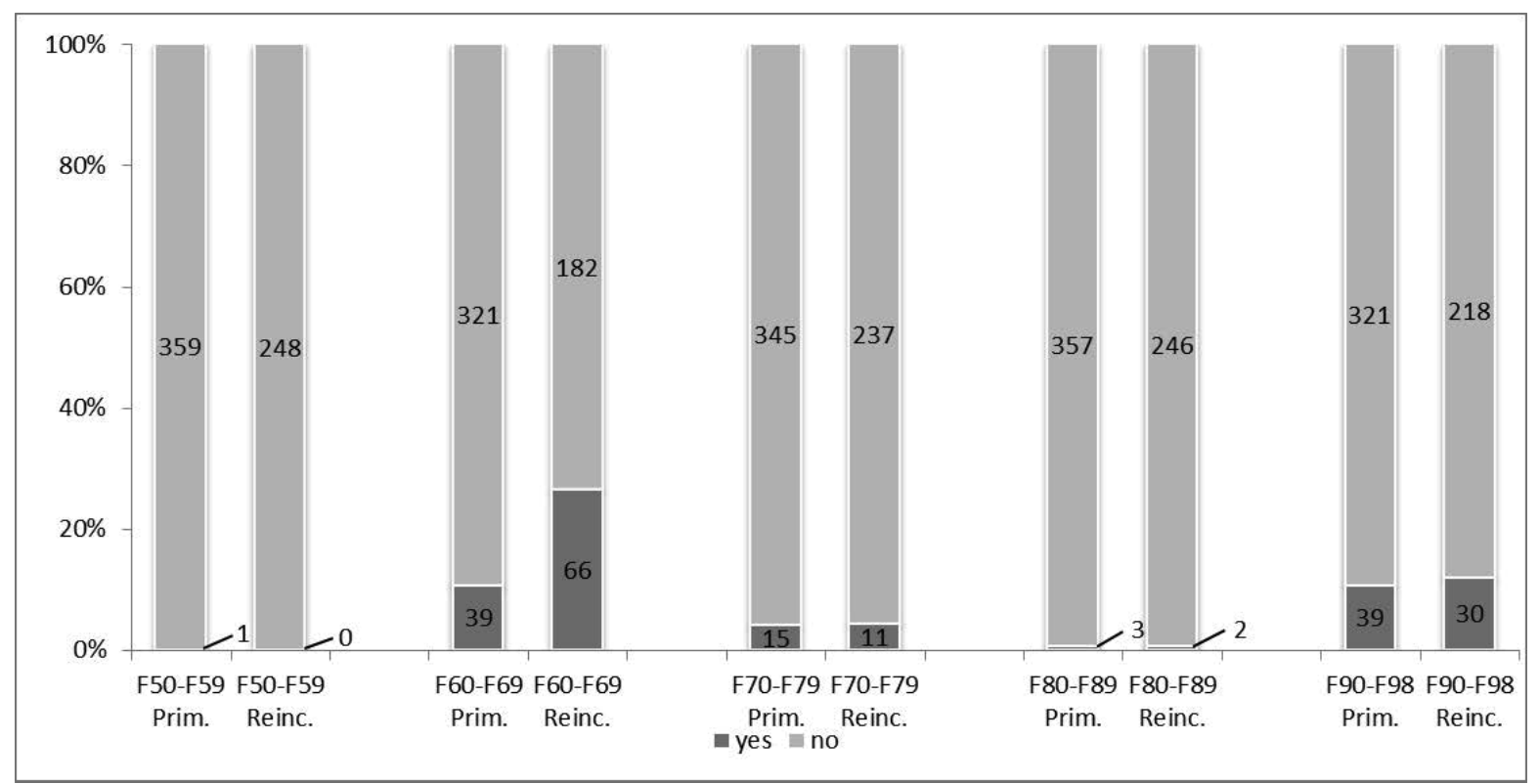

Figure 2. Psychiatric associations to primary offenders and recidivism for F50-F98 (ICD-10). 


\section{Associations with Recidivism}

As suggested by the analyses, the categories 'Behavioral Disorders due to Psychoactive Substance Use' and 'Disorders of Adult Personality and Behavior' are associated with recidivism (both $p<.001$ ), while 'Organic, including Symptomatic, Mental Disorders', 'Mood [affective] Disorders', and 'Neurotic, Stress-Related and Somatoform Disorders (categories)' are associated with primary offenders ( $\mathrm{p}<.001 ; p=.05 ; p<.001$, respectively).

\section{Discussion}

\section{Tendencies among Brazilian Juvenile Offenders}

Although our results in general show similarities regarding the prevalence of anxiety, depression and the abuse of substances with other studies of young offenders with mental health problems (Andrade, Assumpção, Teixeira, \& Silva, 2011; Andrade, Silva, \& Assumpção, 2004; Pinho et al., 2006), this is the first time that a comparison between primaries and recidivist offenders has been conducted. This is a relevant point as it may at once help to shed light on the permanent discussion of whether mental disorders are a cause or a consequence of incarceration.

By taking into account the statistically relevant subcategories, it is interesting to note that Disorders of Adult Personality and Behavior are composed of several subclasses, among which there is the Dissocial Personality Disorder (F 60.2), traditionally linked with misdemeanor (11). In that sense, we also tested the hypothesis that this particular trait had a specific role in the inter-group differences that were ascertained. We specifically found that among the 39 primaries that received a diagnosis pertaining to this sub-category, 17 had a dissocial personality disorder (.44), while among the 66 recidivists, 47 were diagnosed with a dissocial personality disorder (.71). These results therefore suggest that a dissocial personality disorder is the core sub-category unbalancing the diagnostic distribution.

It is hard to define whether this is a cause or an effect of commitment to a criminal life, but there are some indirect indications that the latter is at least partly correct, since the mean age of both groups is basically the same, and close to the upper limit by which a youngster can be judged under the terms of the juvenile correctional system.

The same procedure was performed with Mood [affective] Disorders (predictor of primary offenders), where we hypothesized that depression could have had a prominent role within the great inter-group differences that were found. To test that hypothesis, the sub-class F-32 (Depressive Episode) was analyzed separately. The result was that depression was present among .49 of the primaries diagnosed in this sub-category, and among .34 of recidivists. In absolute terms, there were 10 cases of depression among recidivists (.02) and 31 cases among primaries (.05). According to our perspective, these last findings can be associated with the high proportion of dissocial personality disorders in the recidivist cohort, suggesting that emotional reactivity represents an axis of psychiatric predictors, where the two ends would be associated with primary offenders (high levels of emotional reaction) and recidivism (low levels of emotional reaction). Alternatively, though, it is also possible that the psychological distress of a first incarceration could be greater than any subsequent commitments, thus leading to a greater mood and anxiety disorder prevalence.

It is important to note that mood or stress related disorders might not lead to crime, but rather represent a reaction to incarceration. Further studies are needed in order to better understand this matter, although this survey's standpoint (based on more than 800 interviews) is that it is unlikely that such associations represent predictors of primary offenders in this cohort. This perspective has two important consequences for current research: in the first place, it suggests that while some disorders predict incarceration, some are predicted to only extend to primaries. In the second place, it suggests the importance of temporarily excluding mood-and-stress-related categories, in order to have a fair picture of the associations that are more than likely to represent 'predictors of primary offenders' in this cohort.

From that perspective, drug abuse would represent .34 of all psychiatric records, jumping to the first position among the predictors of incarceration; and instead of .58, there would be .30 primaries suffering from psychiatric disorders that represent risk factors for incarceration. This procedure also reveals that drug abuse represents the most widespread risk factor for all groups. Additionally, the only psychiatric predictor of recidivism is dissocial personality.

Therefore, it seems reasonable to assume that for many of the youngsters (and especially for those who will become recidivists), becoming addicted to drugs is a passport to crime, while the impossibility of kicking the habit also favors recidivism. Whether addiction increases other criminal leanings, so as to obtain resources to buy drugs (it would be reasonable to assume this when considering it in relation to most developed countries), is a matter of discussion - however, it is a well-known fact that many poor teenagers in Brazil use very low-cost narcotics (e.g. solvents present in shoe-fixing glue), which are cheaper than food.

\section{Conclusion}

This study mapped and compared the presence of psychiatric disorders in primary and recidivist Brazilian youngsters, facing socio-educational sentences in correctional facilities, in the city of Sao Paulo. Within the main results, we found that it would be reasonable to consider differences in emotional reactivity as an axis for the differentiation of psychiatric connections for primaries and recidivists. This perspective is based upon the fact that primaries represent a higher tendency to manifest affective symptoms (majorly depressive), while recidivists show a higher tendency to manifest dissocial behavior and a higher incidence of drug abuse. Furthermore, it is important to 
discriminate reactional disorders from potential predictors of crime; further studies are needed to address such question, mainly a longitudinal research.

\section{References}

Amorim, P. (2000). Mini International Neuropsychiatric Interview (MINI): Validação de entrevista breve para diagnóstico de transtornos mentais. Revista Brasileira de Psiquiatria, 22(3), 106-115.

Andrade, R. C., Assumpção, F. B., Jr., Teixeira, I. A., \& Silva, V. A. (2011). Prevalence of psychiatric disorders in juvenile offenders in the city of Rio de Janeiro (RJ, Brazil): Comparison between genders and relation to the severity of the offense. Ciência e Saúde Coletiva, 16(4), 2179-2188.

Andrade, R. C., Silva, V. A., \& Assumpção, F. B., Jr. (2004). Prevalence of psychiatric disorders in Brazilian juvenile delinquents. Brazilian Journal of Medical and Biological Research, 37(8), 1155-1160.

Brennan, P., \& Raine, A. (1997). Biosocial bases of antisocial behavior: Psychophysiological, neurological, and cognitive factors. Clinical Psychology Review, 17(6), 589-604.

Cruzeiro, A. L. S., Silva, R. A, Horta, B. L., Souza, L. D. M., Faria, A. D., Pinheiro, R. T., ...Ferreira, C. D. (2008). Prevalência e fatores associados ao transtorno da conduta entre adolescentes: Um estudo de base populacional. Cadernos de Saúde Pública, 24(9), 2013-2020.

Eppright, T., Kashani, J., Robison, B., \& Reid, J. (1993). Comorbidity of conduct disorder and personality disorders in an incarcerated juvenile population. American Journal of Psychiatry, 150(8), 1233-1236.

Ferigolo, M., Barbosa, F. S., Malysz, A. S., Stein, A. T., \& Barros, H. M. T. (2004). Drug use prevalence at FEBEM, Porto Alegre. Revista Brasileira de Psiquiatria, 26(1), 10-16.

Gallo, A. E., \& Williams, L. C. A. (2005). Adolescentes em conflito com a lei: Uma revisão dos fatores de risco para a conduta infracional. Psicologia: Teoria e Prática, 7(1), 81-95.

Kohler, D., Heinzen, H., Hinrichs, G., \& Huchzermeier, C. (2009). The prevalence of mental disorders in a German sample of male incarcerated juvenile offenders. International Journal of Offender Therapy and Comparative Criminology, 53(2), 211-227.

Mendes, D. D., Mari, J. J., Singer, M., Barros, G. M., \& Mello, A. F. (2009). Estudo de revisão dos fatores biológicos, sociais e ambientais associados com o comportamento agressivo. Revista Brasileira de Psiquiatria, 31(Supl. 2), S77-S85.

Pinho, S. R., Dunningham, W., Aguiar, W. M., Andrade, A. S., Filho, \& Guimarães, K. (2006). Psychiatric morbidity among adolescents in conflict with the law. Jornal Brasileiro de Psiquiatria, 55, 126-130.

Sheehan, D. V., Lecrubier, Y., Sheehan, K. H., Amorim, P., Janavs, J., Weiller, E., ...Dunbar, G. C. (1998). The MiniInternational Neuropsychiatric Interview (M.I.N.I.): The development and validation of a structured diagnostic psychiatric interview for DSM-IV and ICD-10. Journal of Clinical Psychiatry, 59(Suppl. 20), 22-33.

Teplin, L. A, Abram, K. M., McClelland, G. M., Dulcan, M. K., \& Mericle, A. A. (2002). Psychiatric disorders in youth in juvenile detention. Archives of General Psychiatry, 59(12), 1133-1143.
Ulzen, T., \& Hamilton, H. (1998). The nature and characteristics of psychiatric comorbidity in incarcerated adolescents. Canadian Journal of Psychiatry, 43(1), 57-63.

Vreugdenhil, C., Doreleijers, T. A. H., Vermeiren, R., Wouters, L. F. J. M., \& Van Den Brink, W. (2004). Psychiatric disorders in a representative sample of incarcerated boys in The Netherlands. Journal of Amererican Academy of Children \& Adolescent Psychiatry, 43(1), 97-104. 